\title{
SISTEM PENDUKUNG KEPUTUSAN PEMBERIAN BONUS KARYAWAN MENGGUNAKAN METODE AHP
}

\author{
Nuriadi Manurung ${ }^{1}$ \\ Sekolah Tinggi Manajemen Informatika Komputer Royal Kisaran, Asahan
}

${ }^{1}$ nuriadi 22@yahoo.co.id

\begin{abstract}
Abstrak - Dalam setiap perusahaan, instansi, organisasi atau badan usaha akan memberikan gaji sebagai kompensasi dari kerja seorang karyawan, disamping pemberian gaji pokok pada karyawannya, setiap instansi seringkali memberikan bonus gaji disamping gaji pokok untuk memacu kinerja dan produktifitas kerja karyawannya. Adapun cara yang digunakan adalah dengan melakukan pemilihan karyawan yang sesuai kriteria oleh pimpinan, bonus gaji diberikan bersamaan dengan pemberian gaji setiap bulannya. Kriteria untuk menentukan karyawan yang memiliki prioritas untuk mendapatkan bonus gaji meliputi tanggung jawab,sikap kerja,dan kejujuran.Selain masih menggunakan sistem konvensional,kedekatan pimpinan dengan karyawan sering kali menghasilkan keputusan yang berbeda dari yang semestinya hal ini menyebabkan hasil keputusannya menjadi tidak tepat Permasalahan dalam penelitian ini adalah bagaimana membangun sistem pendukung keputusan menggunakan metode AHP untuk membantu pimpinan perusahaan dalam menentukan karyawan yang berhak menerima bonus.
\end{abstract}

Kata Kunci : Bonus Karyawan,AHP, Pendukung Keputusan.

Abstract - In any company, agency, organization or business entity will provide salary as compensation from an employee's employment, in addition to providing basic salary to employees, each agency often provides salary bonuses in addition to basic salaries to spur employee performance and productivity. The way that is used is to make the selection of employees who match the criteria by the leader, salary bonus given along with monthly salary. The criteria for determining employees who have priority to earn salary bonuses include responsibility, work attitude, and honesty. In addition to using conventional systems, the proximity of the employee leads to decisions that differ from those that should result in improper results. This research is how to build decision support system using AHP method to assist company leadership in determining employee entitled to receive bonus.

Keywords: Employee Bonus, AHP, Decision Support System.

\section{PENDAHULUAN}

Dalam setiap perusahaan, instansi, organisasi atau badan usaha akan memberikan gaji sebagai kompensasi dari kerja seorang karyawan, disamping pemberian gaji pokok pada karyawannya, setiap instansi seringkali memberikan bonus gaji disamping gaji pokok untuk memacu kinerja dan produktifitas kerja karyawannya. Permata Permai Service adalah sebuah badan usaha yang bergerak di bidang perbaikan mesin dan service mobil dengan jumlah karyawan yang lumayan banyak. Yang selama ini masih menggunakan sistem konvensional untuk menentukan karyawan 
yang berhak mendapat bonus gaji. Adapun cara yang digunakan adalah dengan melakukan pemilihan karyawan yang sesuai kriteria oleh pimpinan bengkel. Bonus gaji diberikan bersamaan dengan pemberian gaji setiap bulannya. Kriteria untuk menentukan karyawan yang memiliki prioritas untuk mendapatkan bonus gaji meliputi kehadiran,tanggung jawab, kejujuran, dan sikap kerja. Selain masih menggunakan sistem konvensional, kedekatan pimpinan dengan karyawan sering kali menghasilkan keputusan yang berbeda dari yang semestinya hal ini menyebabkan hasil keputusannya menjadi tidak tepat.

Sistem ini tidak dimaksudkan untuk menggantikan fungsi seorang pimpinan dalam mengambil keputusan tetapi hanya untuk membantu pimpinan dalam mengambil sebuah keputusan secara lebih cepat dan tepat, sesuai dengan kriteria yang diinginkan atau setidaknya mendekati kriteria yang diinginkan. Alternatifalternatif pilihan yang diharapkan dapat memberikan daftar referensi kepada pembuat keputusan sebelum benar - benar mengambil suatu keputusan akhir. Sistem pendukung keputusan ini menggunakan metode AHP (Analytic Hierarchy Process) karena memiliki banyak keunggulan dalam menjelaskan proses pengambilan keputusan dengan menggunakan kriteria-kriteria tertentu sehingga dapat membantu kinerja pimpinan dalam menentukan keputusan.

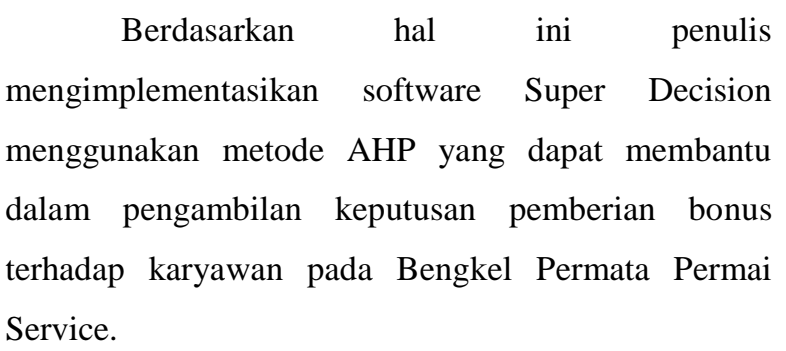

\section{A. Karyawan}

Karyawan adalah orang yang menjual jasa (pikiran) atau tenaga) dan mendapat kompensasi yang besarnya telah ditetapkan terlebih dahulu (Hasibuan

Manulang,2002).

\section{B. Bonus Karyawan}

Bonus karyawan merupakan sesuatu yang mendorong tau mempunyai kecenderungan untuk merangsang suatu kegiatan, bonus ialah motif-motif dan imbalanimbalan yang dibentuk untuk memperbaiki produksi (Menurut Andrew F.Sikula).

\section{Pengertian Sistem Pendukung Keputusan}

Menurut Alter [5],Sistem Pendukung Keputusan merupakan sistem informasi yang mnyediakan informasi, pemodelandan manipulasi data. Sistem itu digunakan untuk membantu pengambilan keputusan dalam situasi yang semiterstruktur,dimana tak seorang pun tahu secara pasti bagaimana keputusan seharusnya dibuat.

\section{Metode AHP}

Analytic Hierarki Proses (AHP) merupakan suatu model pendukung keputusan yang dikembangkan oleh Thomas L. Saaty. Model pendukung keputusan ini akan menguraikan masalah multi faktor atau multi kriteria yang kompleks menjadi suatu hirarki [5]. Dengan AHP permasalahan yang kompleks dapa diselesaikan dengan kerangka piki terorganisir, sehingga memungkinkan untuk diaplikasikan untuk pengambilan keputusan yang efektif dan efisien. Persoalan yang kompleks dapat diselesaikan dengan sederhana dan dipercepat proses pengambilan keputusannya.

\section{E. Prinsip dasar AHP}

Ada beberapa prinsip dasar yang harus dipahami dalam penyelesaian AHP [5]: 
1. Membuat Hierarkhi

Sistem yang kompleks bisa dipahami dengan memecahnya menjadi elemen elemen pendukung, menyusun elemen secara hierarki, dan menggabungkannya.

2. Penilaian kriteria dan alternatif

Kriteria dan alternatif dilakukan dengan perbandingan berpasangan. Menurut Saaty [5] untuk berbagai persoalan skala 1 sampai 9 adalah skala terbaik dalam meberikan pendapat. Dalam perbandingan ini dapat diukur dengan menggunakan tabel analisis.

Tabel 1 Skala-skala perbandingan berpasangan

\begin{tabular}{|c|c|}
\hline $\begin{array}{c}\text { Intensitas } \\
\text { Kepentingan }\end{array}$ & Keterangan \\
\hline 1 & Kedua elemen sama pentingnya \\
\hline 3 & $\begin{array}{l}\text { Elemen yang satu sedikit lebih penting daripada } \\
\text { elemen yang lainnya }\end{array}$ \\
\hline 5 & Elemen yang satu lebih penting daripada yang lainnya \\
\hline 7 & $\begin{array}{l}\text { Satu elemen jelas lebih mutlak penting daripada } \\
\text { elemen lainnya }\end{array}$ \\
\hline 9 & Satu elemen mutlak penting daripada elemen lainnya \\
\hline $2,4,6,8$ & $\begin{array}{l}\text { Nilai-nilai antara dua nilai pertimbangan- } \\
\text { pertimbangan yang berdekatan }\end{array}$ \\
\hline
\end{tabular}

3. Menentukan prioritas

Untuk setiap kriteria dan alternatif perlu dilakukan perbandingan berpasangan (pairwaise comparisons). Nilai-nilai perbandingan relatif dari seluruh alternatif kriteria bisa disesuaikan dengan judgement yang telah ditentukan untuk menghasilkan bobot dan prioritas.

4. Konsistensi logis

Menyangkut tingkat hubungan antar objek yang didasarkan pada kriteria tertentu.

\section{F. Tahapan $A H P$}

Prosedur atau langkah langkah dalam metode AHP sebagai berikut [5]:

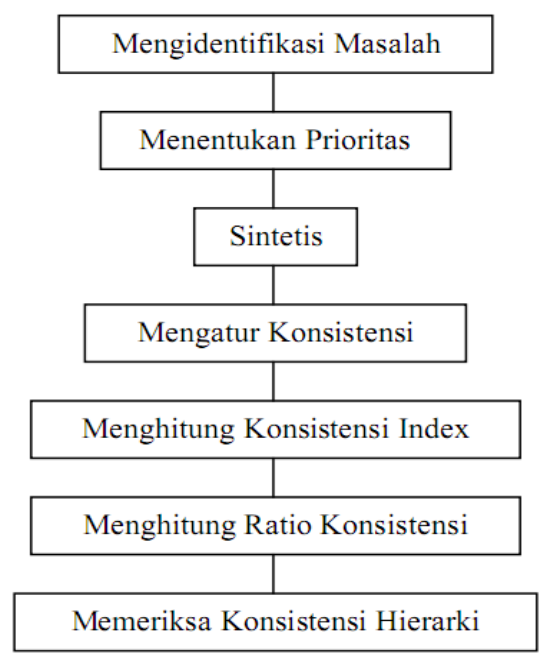

Gambari 1 Tahapan AHP

1. Mendifinisikan masalah dan menentukan solusi yang diinginkan, kemudian menyusun hierarkhi dari permasalahan yang dihadapi.

2. Menentukan prioritas elemen

a. Membuat perbandingan berpasangan, yaitu membandingkan elemen secara berpasangan sesuai kriteria yang diberikan.

b. Matriks perbandingan berpasangan diisi menggunakan bilangan untuk mempresentasikan kepentingan relativ dari suatu elemen terhadap elemen yang lainnya.

3. Sintesis

Pertimbangan pertimbangan terhadap perbandingan berpasangan di sintesis untuk memperoleh keseluruhan prioritas. Hal hal yang dilakukan adalah:

a. Menjumlahkan nilai nilai dari setiap kolom pada matriks. 
b. Membagi setiap nilai dari kolom dengan total kolom yang bersangkutan untuk memperoleh normalisasi matriks.

c. Menjumlahkan nilai nilai dari setiap baris dan membaginya dengan jumlah elemen untuk mendapatkan nilai rata rata.

d. Mengukur konsistensi.

e. Menghitung consistency index (CI) dengan rumus:

\section{CI : $(\lambda$ Maks-N $) / \mathrm{N}$}

dimana:

$\mathrm{N}$ : banyaknya elemen (kriteria)

f. Hitung Ratio Konsistensi (CR) dengan rumus: $\mathrm{CR}$ : $\mathrm{CI} / \mathrm{CR}$

dimana:

CR: Concictency Ratio

CI: Consistency Index

IR: Indeks Random Concictency,

Tabel 2 Daftar Indeks Random Consistency (IR)

\begin{tabular}{|c|c|c|c|}
\hline $\begin{array}{c}\text { Ukuran } \\
\text { Matriks }\end{array}$ & $\begin{array}{c}\text { Nilai } \\
\text { IR }\end{array}$ & $\begin{array}{c}\text { Ukuran } \\
\text { Matriks }\end{array}$ & $\begin{array}{c}\text { Nilai } \\
\text { IR }\end{array}$ \\
\hline 1,2 & 0,00 & 8 & 1,41 \\
\hline 3 & 0,58 & 9 & 1,45 \\
\hline 4 & 0,90 & 10 & 1,49 \\
\hline 5 & 1,12 & 11 & 1,51 \\
\hline 6 & 1,24 & 12 & 1,48 \\
\hline 7 & 1,32 & & \\
\hline
\end{tabular}

g. Memeriksa konsistensi hierarkhi

Jika nilai lebih dari $10 \%$, maka penilaian data judgement harus diperbaiki. Namun jika Rasio Consisten (CR) kurang dari atau 0,1 , maka hasil perhitungan bisa di nyatakan benar .

\section{METODOLOGI PENELITIAN}

a. Observasi

Pada penelitian ini dimulai dengan melakukan observasi lapangan untuk mencari bahasan penelitian pada Bengkel Permata Permai.

b. Definisi Masalah

Pada tahapan ini melihat permasalahan yang akan diangkat,kriteria yang diperlukan dalam proses penilaian.

c. Studi literatur.

Selanjutnya mencari studi literatur mengenai tinjauan pustaka yang berkaitan dengan penelitian yang akan dilaksanakan serta literatur penelitian sebelumnya yang terkait dengan tema penelitian.

d. Metode yang digunakan adalah metode AHP yaitu Model pendukung keputusan yang akan menguraikan masalah multi faktor atau multi kriteria yang kompleks menjadi suatu hirarki.hirarki didefinisikan sebagai suatu representasi dari sebuah permasalahan yang kompleks dalam suatu struktur multi level dimana level pertama adalah tujuan. Dengan metode ini diharapkan adanya penilaian yang lebih akurat.

e. Metode Pengumpulan Data

Peneliti menggunakan teknik pengumpulan data dengan melakukan wawancara

\section{HASIL DAN PEMBAHASAN}

Berikut ini adalah implementasi perhitungan data dengan metode yang dipilih yaitu metode AHP :

Tabel 3 Perbandingan Kriteria

\begin{tabular}{|c|c|c|c|c|c|c|c|c|}
\hline Kategori & Tanggung Jarrab & Sikap Kerja & Kejujuran & \multicolumn{3}{|c|}{ Membagi Nilai Eigen } & Jumlah & Rata-Rata \\
\hline Tanggung Jawab & 1 & 3 & 0,5 & 0,3000 & 0,3333 & 0,2941 & 0,9275 & 0,3092 \\
\hline Sikap K & 0,3333333333 & 1 & 0,2 & 0,1000 & 0,1111 & 0,1176 & 0,3288 & 0,1096 \\
\hline Kejujuu & 2 & 5 & 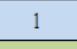 & 0,6000 & 0,5556 & 0,5882 & 1,7438 & 0,5813 \\
\hline ЛМLAH & 3,333333333 & 9 & 1,7 & 1 & 1 & 1 & 3 & \\
\hline
\end{tabular}


Selanjutnya menentukan nilai perbandingan antara kriteria tanggung jawab terhadap setiap alternatif/karyawan. Tampak pada hasil tabel berikut.

Tabel 4 Perbandingan Kriteria Tanggungjawab dan Alternative

\begin{tabular}{|c|c|c|c|c|c|c|c|c|c|c|c|c|c|}
\hline Tanggung jarab & Soffan & Deri & Darma & Andi & Fauxi & Budi & \multicolumn{6}{|c|}{ Membagi Nilai Eigen } & Rata-Rata \\
\hline Soffan & 1 & 2 & 3 & 5 & 3 & 4 & 0,382 & 0,429 & 0,345 & 0,417 & 0,333 & 0,235 & 0,35681 \\
\hline Deri & 0,5 & 1 & 2 & 3 & 2 & 3 & 0,191 & 0,214 & 0,23 & 0.25 & 0,222 & 0,176 & 0,213991 \\
\hline Darma & 0,3333 & 0,5 & 1 & 2 & 0,5 & 5 & 0,127 & 0,107 & 0,115 & 0,167 & 0,056 & 0,294 & 0,144302 \\
\hline Andi & 0,2 & 0,3333 & 0,5 & 1 & 2 & 2 & 0,076 & 0,071 & 0,057 & 0,083 & 0,222 & 0,118 & 0,104756 \\
\hline Fausy & 0,3333 & 0,5 & 2 & 0,5 & 1 & 2 & 0,127 & 0,107 & 0,23 & 0,042 & 0,111 & 0,118 & 0,122474 \\
\hline Budi & 0,25 & 0,3333 & 0,2 & 0,5 & 0,5 & 1 & 0,096 & 0,071 & 0,023 & 0,042 & 0,056 & 0,059 & 0,057667 \\
\hline Jumlah & 2,6167 & 4,6667 & 8,7 & 12 & 9 & 17 & 1 & 1 & 1 & 1 & 1 & 1 & 1 \\
\hline
\end{tabular}

Selanjutnya menentukan nilai perbandingan antara kriteria Sikap Kerja terhadap setiap alternatif/ karyawan. Tampak pada hasil tabel berikut.

Tabel 5 Perbandingan Alternative Sikap Kerja dan

Alternative

\begin{tabular}{|c|c|c|c|c|c|c|c|c|c|c|c|c|c|}
\hline Sikap Kerja & Soffyan & Deri & Darma & Andi & Fauzi & Budi & \multicolumn{6}{|c|}{ Membagi Vilai Eigen } & Rata-Rata \\
\hline Soffan & 1 & 2 & 5 & 7 & 2 & 3 & 0,374 & 0,441 & 0,349 & 0,28 & 0,209 & 0,417 & 0,34484 \\
\hline Deri & 0,5 & 1 & 3 & 5 & 4 & 2 & 0,187 & 0,221 & 0,209 & 0,2 & 0,417 & 0,278 & 0,251982 \\
\hline Darma & 0,2 & 0,3333 & 1 & 3 & 0,3333 & 0,5 & 0,075 & 0,074 & 0,07 & 0,12 & 0,035 & 0,069 & 0,07371 \\
\hline Andi & 0,1429 & 0,2 & 0,3333 & 1 & 0,25 & 0,2 & 0,053 & 0,044 & 0,023 & 0,04 & 0,026 & 0,028 & 0,03577 \\
\hline Faucy & 0,5 & 0,5 & 3 & 4 & 1 & 0,5 & 0,187 & 0,11 & 0,209 & 0,16 & 0,104 & 0,069 & 0,140037 \\
\hline Budi & 0,3333 & 0,5 & 2 & 5 & 2 & 1 & 0,125 & 0,11 & 0,14 & 0,2 & 0,209 & 0,139 & 0,153661 \\
\hline Jumlah & 2,6762 & 4,5333 & 14,333 & 25 & 9,5833 & 7,2 & 1 & 1 & 1 & 1 & 1 & 1 & 1 \\
\hline
\end{tabular}

Selanjutnya menentukan nilai perbandingan antara kriteria Jujur terhadap setiap alternatif/karyawan. Tampak pada hasil tabel berikut.

Tabel 6 Perbandingan Alternative Kejujuran dan Alternative

\begin{tabular}{|c|c|c|c|c|c|c|c|c|c|c|c|c|c|}
\hline $\mathbf{R} \in[u]$ & fyan & Deri & Darma & Andi & Fauxi & Budi & \multicolumn{6}{|c|}{ Membagi Nilai Eigen } & Rata-R \\
\hline ofyan & & 0,3333 & & & & 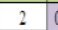 & 0,186 & 0,111 & 0,37 & 0.286 & 0.246 & 0,324 & 0.25396 \\
\hline eri & & 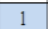 & 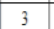 & & & 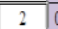 & 0.559 & 0.333 & 0.222 & 0,19 & 0.246 & 0,324 & 0,312544 \\
\hline Darma & & 0,3333 & 1 & & & 0,3333 & 0,037 & 0,111 & 0,074 & 0,048 & 0,164 & 0,054 & \\
\hline Andi & & 0,5 & & & & 0,5 & 0,062 & 0,167 & 0,148 & 0,095 & 0,016 & 0,081 & \\
\hline aux & 333 & 0,3333 & 0,5 & & & 0,3333 & 0,062 & 0,111 & 0,037 & 0,19 & 0,082 & 0,054 & 0,089 \\
\hline sudi & 0 & 0,5 & 2 & 2 & & 1 & 0,093 & 0,167 & 0,148 & 0,19 & 0,246 & 0,162 & 0,167754 \\
\hline Jumlah & 5,3667 & 3 & 13,5 & 10,5 & 12,2 & 6,1667 & 1 & 1 & 1 & 1 & 1 & 1 & 1 \\
\hline
\end{tabular}

Selanjutnya adalah mentukan preperensi sebagai acuan dalam menyusun hasil perengkingan . Tampak pada tabel berikut.
Tabel 7 Perangkingan

\begin{tabular}{|l|c|c|}
\hline Sofyan & 0,295714976 & 1 \\
\hline Deri & 0,275439576 & 2 \\
\hline Darma & 0,099970536 & 5 \\
\hline Andi & 0,091490298 & 6 \\
\hline Fauzi & 0,105208422 & 4 \\
\hline Budi & 0,132176191 & 3 \\
\hline
\end{tabular}

Menurut penerapan sistem pendukung keputusan yang berhak mendapat bonus adalah karyawan yang memiliki bobot nilai keseleruhan lebih dari 0,21.Maka dari perhitungan diatas menunjukan sofyan dan deri memiliki nilai di atas 0,21.Oleh karena itu mereka berhak mendapatkan bonus gaji sesuai dengan bobot kriteria yang sudah ditetapkan.

\section{KESIMPULAN}

Berdasarkan penelitian yang telah dilakukan di Bengkel Permata Permai Service maka dapat disimpulkan bahwa sistem pendukung keputusan ini cukup efektif untuk mengatasi masalah pemberian bonus gaji karyawan yang dianggap kurang adil dan kurang efektif. Dengan menggunakan metode AHP, penilaian karyawan dapat dihitung dan dapat menentukan karyawan manakah yang berhak mendapatkan bonus gaji. Sehingga sistem ini dapat bermanfaat membantu manager dalam menentukan karyawan yang berhak mendapatkan bonus seperti tujuan dibuatnya program ini.

\section{SARAN}

Saran yang dapat diberikan penulis untuk pengembangan selanjutnya yaitu dapat dikembangkan dengan teori AHP dari para ahli lainnya, seperti Yudhistira dan Lee dengan studi kasus yang sama 
ataupun berbeda. Sehingga dapat dilihat perbandingan keputusan yang dihasilkan dari beberapa teori.

\section{DAFTAR PUSTAKA}

1] Aulia, R., 2013, Sistem Pendukung Keputusan Seleksi Penerimaan Beasiswa Di STTH Medan, Seminar Nasional Teknologi Informasi dan Komunikasi (SNASTIKOM 2013), Medan, 1314 Maret 2013

[2] Azmi, M., Sonatha, Y., Rasyidah, 2014, Pemanfaatan Sistem Pendukung Keputusan Untuk Penentuan Alokasi Dana Kegiatan (Studi Kasus Unit Kegiatan Mahasiswa Politeknik Negeri Padang), Jurnal Momentum, Vol 16, No 1, Hal 74-83.

[3] Jogiyanto, 2005. Analisis dan Desain Sistem Informasi, Penerbit Andi. Yogyakarta.

[4] Kadir Abdu,. 2007. Pengenalasn Sistem Informasi. Penerbit Andi. Yogyakarta.

[5] Kusrini. 2007. KonsepdanAplikasiSistemPendukungKeputusan. Yogyakarta: Andi.

[6] Rejeki, Miswatri, Maret 2013, "Sistem Pendukung Keputusan Penentuan Kenaikan Gaji Karyawan Pada Sembada GarmentYogyakarta”. Jurnal Publikasi STIMIK AMIKOM Jogja. 